\title{
Participatory Relief Management: The Experience of the Relief Society of Tigray
}

\author{
Techliwoini Assefaw
}

This paper discusses the experiences of the Relief Society of Tigray (REST) and the people of rural Tigray during the Ethiopian famine of 1984-85. This experience was unique and has not been widely publicized internationally.

Despite war and drought, in 1985 there was a system in Tigray for providing assistance to victims of the Ethiopian famine. This system was based on a partnership between REST, various civilian departments of the Tigrayan People's Liberation Front (TPLF) and local communities who were directly involved in decision making and implementation of the relief operation. Although there was very little international assistance from mid-1984 to late 1985 at the height of the famine, which took a terrible toll on the lives and livelihood of rural people, this participatory form of relief management enabled the Tigrayans to survive the worst period in their history, and to move forward and rebuild their lives.

In this paper, I will concentrate on the events and policy decisions that led to the organized exodus of some 200,000 Tigrayans to eastern Sudan, beginning in October 1984, and their repatriation to Tigray between 1985 and 1987. However, to begin I will provide a brief background to the context we were operating in at the time of the famine. Finally I will consider some of the main issues arising from the events considered here.

\section{Background}

The Relief Society of Tigray was founded as a humanitarian organization in 1978, three years after the war between the central government of Mengistu Haile Mariam and the Tigrayan People's Liberation Front began. REST's mandate was to assist drought- and war-affected people living in the areas of Tigray under

Techliwoini Assefaw is the director of the Relief Society of Tigray in Addis Ababa. the control and administration of the TPLF. After 1980, a few northern nongovernmental organizations gave REST a small amount of funds, for purchasing grain surpluses in the western part of Tigray. REST redistributed the grain to drought-affected regions. REST also operated a small fleet of trucks to transport emergency food aid from Sudan across the border to western Tigray.

Unfortunately, this cross-border operation was insufficientin meeting the requirements of the rural population, many of whom were forced by consecutive years of drought and failed harvests to sell off their assets for food. The drought has intensified and the war escalated. Between 1980 and 1985 the Ethiopian government launched five major ground and air offensives against rural areas under the control of the TPLF. These offensives gravely exacerbated the effects of drought by disrupting food production. Tens of thousands of displaced people were added to the growing number of those displaced due to drought. The war also severely constrained the relief operation. REST delivered and distributed food only at night to avoid bombardment.

Despite these conditions, from 1975 onwards there was a steady development of a system of local government in the TPLF-controlled areas that were historically characterized by feudalism. This system consisted of democratically elected village committees, which in turn elected representatives to district (woreda) committees. These woreda committees, known as Baitos, became the foundation of a civilian government in Tigray. They also implemented a series of social welfare and agricultural development programs initiated by the TPLF. The Baitos also formed a partnership with REST in managing reliefoperations. As a result, REST was able to obtain regular and detailed accounts of the rural people's needs and priorities, while the
Baitos were responsible for carrying out relief distribution.

\section{The Famine Crisis of $1984-85$}

In 1983, a Drought Commission was established in TPLF-controlled areas of Tigray to manage the drought crisis. At that time, 85 percent of Tigray was administered by the TPLF, including almost all of the rural areas, while government forces were confined to garrisoned towns along the main highway. The Drought Commission included REST, the TPLF's public administration department and the Baitos. Meanwhile, the number of people who were internally displaced by the drought increased. In 1980, REST recorded some 6,000 households from central Tigray that were displaced to the western region. By July 1983, this number had risen to over 400,000 people.

In response to the growing disaster, the Drought Commission held a series of consultations with Baito representatives throughout Tigray to discuss how people could obtain food. One possibility was migration from the most droughtstricken central and eastern regions to REST's emergency centres and food distribution sites in the west. However, REST's capacity to support people in western Tigray was already constrained by the limited aid resources at its disposal. People were thus encouraged to try to find jobs in the west or any other areas that traditionally offered seasonal employment. Meanwhile, REST attempted to obtain more support from donors for its relief programs.

At the same time, it was clear that the grain purchasing and food distribution programs were insufficient. Consequently, the TPLF issued a number of requests to the international community to support the safe passage of relief assistance from the towns into the famineaffected countryside. Several countries responded and attempted to negotiate a

Refuge, Vol. 12, No. 8 (March 1993) 
safe passage agreement with the Ethiopian government.

In 1984 many people who migrated in search of food returned home to try to cultivate their lands during the rainy season. By mid-1984, however, it became apparent that the drought would continue for the fourth consecutive year. Furthermore, there was a lack of rain not only in chronically drought-affected areas, but also in the traditionally surplus-producing western region. Tigray was now in the midst of a major catastrophe.

Although TPLF and REST continued to call for a safe passage agreement, it became obvious that this would not happen in time to save hundreds of thousands of lives. Consequently, the Drought Commission advised people to attempt to obtain food from the international agencies working in the towns, even though this meant crossing military lines. In the early autumn of 1984 , many people tried to obtain food from the towns. At that time, however, the Mengistu government relaunched its program of resettling people from the north to areas in southern Ethiopia. It was reported that people who entered the towns from TPLF-controlled areas were being rounded up for resettlement and forcefully separated from their families by the army. These reports made people extremely wary about entering the towns. Thus hundreds of thousands of people in the central and eastern highlands found themselves trapped with no possibility of obtaining food.

\section{The Exodus to Sudan}

The Drought Commission decided to provide an escape route from the famine zones. In September 1984, the commission called another series of meetings with the Baitos to explain that the TPLF would establish a secure route to Sudan for those who decided to make the journey. However, since REST could not provide food for more than 65,000 people at any time, not all who decided to leave their villages could make the journey at once. Consequently, villages were asked to register for the exodus to Sudan only when all of their remaining resources were exhausted. Once people reached western Tigray, they would be supported at REST transit centres, which were set up along the route. At the same time, REST notified the international community to expect a large-scale influx of Tigrayan refugees in eastern Sudan.

Committees were formed in each village to look after medical care, registration, food supplies and security for the journey. Once villagers were mobilized, they joined other villagers in the vicinity to form groups of approximately 4,000 . Each group was registered by the Drought Commission at a series of checkpoints across Tigray. Those who were unable to walk due to illness were also registered, so that they could be reunited with their families when their condition improved.

\section{Repatriation}

Approximately 200,000 people made the journey to Sudan from the end of 1984 to mid-1985. They left with the intention of returning to Tigray after the dry season and as soon as they were able to resume agricultural production during the next rainy season. Meanwhile, REST, together with international NGOs, provided assistance to those in reception centres in Sudan, while continuing its emergency programs inside Tigray.

Originally, REST planned to repatriate 50,000 households from Sudan in 1985. However, it became clear that there would not be enough food supplies or rehabilitation assistance through the cross-border program to support all Tigrayan refugees that year. After discussions with Baito and village leaders in the refugee camps, REST changed its plans to repatriate 50,000 heads of households who would return home first and cultivate during the growing season while their dependants returned in subsequent years. In this way, dependants could be assured of food supplies in the Sudanese camps, while active producers worked in agricultural production in Tigray.

Meanwhile, conditions in the refugee camps were extremely poor and death rates were very high. Consequently, many dependants wanted to return home in 1985 together with the active producers. This was discussed among village and Baito representatives, and public meetings were held in the refugee camps where people were informed about the limited assistance REST could provide to returnees in 1985. Only those households who had no assets at all in Tigray were eligible to receive rehabilitation inputs from REST.

Although it was described at that time as a "spontaneous return," the repatriation to Tigray was organized in the same manner as the exodus. It occurred over a period of three years with the largest number of people returning home in 1986. Once people returned home, they were registered as returnees from Sudan and reintegrated into the ongoing relief and rehabilitation programs.

In late 1987, after the repatriation program was successfully completed, another cycle of severe drought and crop failure occurred throughout Tigray. Once again, a series of meetings were held with Baito representatives to discuss various options as to how to manage the new crisis.

A return migration to Sudan was one of the choices put before the people. However, they preferred to remain in their villages rather than repeat the movement of 1985. Thus, TPLF and REST decided to expand as quickly as possible the transport routes of the crossborder operation from western Tigray to the central highlands in order to manage the renewed threat of famine. This was feasible because road construction was done the previous year. Also, it was hoped that REST's increased trucking capacity, together with an intensified grain purchasing program, would enable enough food supplies from western Tigray to reach those who were internally displaced. Furthermore, REST requested additional assistance from relief operations in government controlled areas to help support the numbers within the TPLF-controlled areas.

With increased support from international NGOs, this strategy was successful. Most people were able to remain on their land during the dry season, avoid disruptive internal migrations and prepare their fields for cultivation. As a result, there was nosignificant migration 
from Tigray to Sudan that year or the following year.

\section{Issues to Consider}

I would now like to consider some of the key issues from these experiences. The first issue concerns the relationship between the Drought Commission and the Baitos. Without the partnership between these two groups, it would have been virtually impossible to manage a coordinated response to the famine disaster of 1985. One of the most important aspects of this partnership was that the Baito system enabled REST and the TPLF to consult with rural communities throughout Tigray at each stage of the escalating crisis. As a result of these consultations, policy decisions were made based on the experiences and concerns of those affected by the disaster. In this way, an operational framework was created in rural Tigray where people were able to participate in the decisions that affected them. This participation, in turn, created a sense of determination and confidence that mobilized people to survive the famine with whatever meagre means were available to them. It also meant that peopleworked actively with REST and TPLF rather than wait passively for these organizations to solve their problems. As a participant in these events, one of the most moving experiences I witnessed was the tremendous spirit of the people at one of the worst times in their history.

The second issue concerns the role of international NGOs in supporting the relief operation in the TPLF-controlled areas. During the 1985 famine, REST's relief operation was not supported by multilateral organizations that were supporting relief programs in government-controlled areas. This had to do with the politicization of aid to the war zones. Consequently, REST's primary supporters were international NGOs. Those NGOs who supported REST's programs then and in later years demonstrated a flexibility and humanitarianism that saved many lives by providing REST with emergency aid, whilerespecting REST's management of the emergency according to REST's assessment and knowledge of the situation. In turn, REST welcomed the regular monitoring of its program by representatives of international NGOs, which ensured and facilitated its accountability as a humanitarian organization.

This flexible and pragmatic approach towards aid delivery has been duplicated in other similar situations. This kind of approach can also counterbalance the lack of flexibility in multilateral institutions in conflict situations.

Multilateral institutions' inflexibility was particularly noticeable during the 1985 repatriation of Tigrayans from Sudan. Multilateral organizations, particularly the UNHCR, prioritized their institutional mandates and respect for the concept of state sovereignty at the expense of the people's actual needs. It is thus important to recommend that multilateral institutions shift their priorities to ensure that the people's needs are placed first before abstract concepts or organizational procedures. Flexibility can also ensure cooperation within the international community. Furthermore, this approach should be broadened to include not only UN agencies but national and international NGOs as well.

Finally, let me make one final point concerning the repatriation of Tigrayan refugees from Sudan. As mentioned earlier, this movement was part of a broader survival strategy of poor people who knew the importance of returning to their land if they were ever to regain economic self-sufficiency. In effect, this was an extension of the participatory relief management in Tigray. Return to Tigray was facilitated by a participatory framework that enabled the returnees to have confidence in their future. At the time, aid officials in Sudan misinterpreted this confidence for foolhardiness in the refugees' decision to return. Instead, people were able to return home and regain their confidence.

Thus in the Tigrayan case, the people's participation was essential for successful repatriation. This is especially true since very few resources were available to either REST or the TPLF. Within the context of Ethiopia, involving those who are affected in a problem-solving process will ensure that solutions are implemented in the most positive way, even when resources are scarce.
YORK LANES PRESS

Yoik Lanes Press publishes books, monographs and other publica. tions about refugee issues.

RECENT PUBLICATIONS

sooks

Taking Rofuge: Loo budahists In Noth Amorlac.

Penny Van Esterlk

$\$ 12.95$

(copublihed with the southeast aston

Proprom Arizona stato Unversty)

Brooking Ground the 1956

Hungarton Immigration 10

Conode.

Edited by Robert H. Keyserlingk

(Avallable in May 1993)

\section{SPECIAL REPORTS}

Direotory of Arloon Commu. nity Groups in Metro Toronto. Edited by Edward Opoku-

Dapach $\$ 12.50$

Roport on the Workshop tor Afilean Community croups intoromio.

Edited bv Edward Opoku-

Dapaoh $\$ 12.50$

Adeptation of Ehonalan Roluceos in Toronto. Edward Opoku-bapagh (Avalloble in A patl 1903)

To Ropuges crists lin Rusta Eelted by Rozaling f wkina. Rosisiav turovskiy and Roberf Brvm (Avolloble in Apir 1993) Shlpping PJease odd \$2.50 ror one book end 750 for ecch odditional liom. Conadion residents odd $7 \%$ estontho toldamount Plocsesend rout order with poyment of P. 0 . number to:

roktans nos?

Sulte 351 , Yoik Lanes

Yoik Universty

4703 kede stred.

North rork, Ontorso

Canceda May ip3

tet: (416) 736.5913

For $(476) 7365937$

Refuge, Vol. 12, No. 8 (March 1993)

(C) Techliwoini Assefaw, 1993. This open-access work is licensed under a Creative Commons Attribution-NonCommercial 4.0 International License, which permits use, reproduction and distribution in any medium for non-commercial purposes, provided the original author(s) are credited and the original publication in Refuge: Canada's Journal on Refugees is cited. 